\title{
Unexplained recurring high mortality of southern right whale Eubalaena australis calves at Península Valdés, Argentina
}

\author{
Victoria J. Rowntree ${ }^{1,2,3,4, *}$, Marcela M. Uhart ${ }^{1,5}$, Mariano Sironi ${ }^{1,4}$, Andrea Chirife ${ }^{1}$, \\ Matias Di Martino ${ }^{1}$, Luciano La Sala ${ }^{1}$, Luciana Musmeci ${ }^{1,6,7}$, Nadia Mohamed ${ }^{1}$, Julian \\ Andrejuk $^{1}$, Denise McAloose ${ }^{8}$, Juan Emilio Sala ${ }^{1,6}$, Alejandro Carribero ${ }^{9}$, Heather Rally ${ }^{10}$, \\ Marcelo Franco ${ }^{11}$, Frederick R. Adler ${ }^{2}$, Robert. L. Brownell Jr. ${ }^{12}$, Jon Seger ${ }^{2}$, Teri Rowles ${ }^{13}$ \\ ${ }^{1}$ Southern Right Whale Health Monitoring Program, (1920) Puerto Madryn, Chubut, Argentina \\ ${ }^{2}$ Department of Biology, University of Utah, Salt Lake City, Utah 84112, USA \\ ${ }^{3}$ Whale Conservation Institute/Ocean Alliance, Gloucester, Massachusetts 01930, USA \\ ${ }^{4}$ Instituto de Conservación de Ballenas, Ing.Maschwitz, (1623), Prov. De Buenos Aires, Argentina \\ ${ }^{5}$ One Health Institute, University of California, Davis, California 95616, USA \\ ${ }^{6}$ CONICET, Centro Nacional Patagónico, Chubut, Argentina \\ ${ }^{7}$ Fundacion Patagonia Natural, (9120), Puerto Madryn, Argentina \\ ${ }^{8}$ Global Health Program, Wildlife Conservation Society, Bronx, New York 10460, USA \\ ${ }^{9}$ Ecocentro, (9120), Puerto Madryn, Chubut, Argentina \\ ${ }^{10}$ Western University of Health Sciences, College of Veterinary Medicine, Pomona, California 91766, USA \\ ${ }^{11}$ Cuerpo de Guardafaunas, Subsecretaría de Turismo y Áreas Protegidas, Rawson (9103) Chubut, Argentina \\ ${ }^{12}$ Southwest Fisheries Center, NMFS, NOAA, Pacific Grove, California 93950, USA \\ ${ }^{13}$ NMFS, Office of Protected Resources, Silver Spring, Maryland 20910, USA
}

\begin{abstract}
Hundreds of southern right whale calves Eubalaena australis died on their calving ground at Península Valdés, Argentina from 2003 through 2011. During this period, the number of dead calves increased at a much greater rate than that of living calves over the preceding $32 \mathrm{yr}$, and with greater inter-annual variation. High mortality events occurred late in the calving seasons of 2005 and 2007, early in the seasons of 2008 and 2009, and were equally divided between early and late in 2010 and 2011. Calves that died late in the seasons of 2005 and 2007 were at least a meter longer (mean $7.3 \mathrm{~m}$ ) than newborns, indicating that they had grown and presumably were healthy before dying. An unusual number of large calves $(>6 \mathrm{~m})$ died early in the seasons of 2008 and 2009, suggesting that a population-wide process (e.g. nutritional stress) affected many mothers including older, larger mothers that tend to give birth to larger calves early in the season. Many tissue samples have been collected and analyzed, but no consistent lesions, pathologic processes or elevated levels of algal biotoxins have been identified to explain these recent mortality events. Here, we document the high mortality events, place them in historical context and describe ongoing efforts to identify their causes. As of 2010, the southern right whale sub-population that calves off Península Valdés was estimated to be less than $20 \%$ of its initial size before whaling; the ongoing high mortality of calves will significantly affect its recovery.
\end{abstract}

KEY WORDS: Right whale $\cdot$ Mortality $\cdot$ Eubalaena australis $\cdot$ Strandings $\cdot$ Patagonia

\section{INTRODUCTION}

Nineteenth-century whaling severely reduced right whale Eubalaena spp. populations in all of the world's oceans. The northern hemisphere species remain endangered with North Pacific right whales Eubalaena japonica numbering around 400 whales in the Okhotsk Sea and 100 elsewhere in the North Pacific 
(IUCN 2013) and fewer than 500 North Atlantic right whales Eubalaena glacialis (Pettis 2009). Southern hemisphere right whales Eubalaena australis are faring better with an estimated population of 11984 distributed over 11 calving grounds (IWC 2001, IWC 2012). All sub-populations that are being systematically monitored are increasing, with the exception of the critically endangered Chile-Peru subpopulation (IUCN 2013). Genetic analyses indicate little exchange of females between calving grounds (Portway 1998, Baker et al. 1999, Patenaude et al. 2007, Valenzuela et al. 2010). In 2009, the major southern right whale (SRW) calving grounds were estimated to include 3373 whales off Argentina, 3864 off South Africa, 1980 off Australia and 2702 off New Zealand (Table 3 in IWC 2012). Before whaling, the total SRW population was estimated to number 55000 to 70000 whales (IWC 2001).

The southern right whales that use Península Valdés (PV), Argentina (see Fig. 1) as a calving ground have been studied since 1971. Aerial surveys have been conducted annually to photo-identify the individual whales present each year, their locations and the presence of calves (Payne 1986). Females usually calve once every 3 yr (Cooke et al. 2001, 2003) and are not often seen on the calving grounds in intervening years (Payne 1986). The normal 3-yr calving interval of right whales Eubalaena spp. includes one year in gestation (Best 1994), one year in lactation and one year recovering energy reserves to support the next pregnancy (Knowlton et al. 1994, Best et al. 2001, Burnell 2001). Apparent calving intervals of 2 , 4 and $5 \mathrm{yr}$ are thought to result from calving failures due to abortion or death of neonates or nursing calves (Knowlton et al. 1994). The PV whales increased at a rate of $6.8 \% \mathrm{yr}^{-1}$ from 1971 to 2000 (Cooke et al. 2003).

The calving season at PV extends from May through December, with peak numbers of whales present at the end of September-early October (Payne 1986). Most calves are born in or near August, although newborns are seen as late as October (Whitehead \& Payne 1981). Mean calf length at birth is 5.5 to $6.1 \mathrm{~m}$ (Best 1981, Whitehead \& Payne 1981, Best \& Rüther 1992), but smaller calves, ranging from 4.5 to $5.5 \mathrm{~m}$, can survive and comprised more than one-fifth of 72 living right whale calves measured off South Africa (Best \& Rüther 1992). Calves grow as much as $3 \mathrm{~m}$ during their 2 to $3 \mathrm{mo}$ on the calving ground (Best \& Rüther 1992) while being nursed by their fasting mothers. Calves have not been seen to feed independently during their first 3 mo of life (Thomas \& Taber 1984). Little food is available at PV in the winter months. Adults begin to feed sporadically in late September and early October on zooplankton blooms that follow spring blooms of phytoplankton (Payne 1995, Sironi 2004, Hoffmeyer et al. 2010) before they depart for the feeding grounds. The whales feed primarily on copepods north of $40^{\circ} \mathrm{S}$, krill south of $50^{\circ} \mathrm{S}$ and on a mixture of both between these latitudes (Tormosov et al. 1998).

Right whale deaths have been recorded at PV since 1971. During the first $30 \mathrm{yr}$ of the study, deaths appeared to increase at a rate similar to the increase in number of whales using the calving ground, but an unexpectedly large number of whales (47) died in 2005 (Uhart et al. 2008), and high mortality events have continued annually with an average of 75 whales dying each year from 2007 through 2011 (see Fig. 2).

Baleen whales rarely die in large numbers at one time and place (NOAA 2013). Other than incidents of ice entrapment, the first known report of a 'multipledeath event' of baleen whales occurred in 1987 when 14 humpback whales Megaptera novaeangliae died in Cape Cod Bay (Massachusetts, USA) after consuming saxitoxin-contaminated mackerel Scomber scombrus (Geraci et al. 1989). Although reports of multiple baleen-whale deaths in one location within a short period of time have increased over the past 2 decades (see Table 1), such events remain less frequent and less deadly than those recorded for toothed whales (Geraci \& Lounsbury 2005, Gulland \& Hall 2007, NOAA 2013), and they appear to have different causes.

Algal species belonging to the genera Alexandrium and Pseudo-nitzchia can produce natural biotoxins (saxitoxin STX and domoic acid DA, respectively) that have been linked to mass mortality and other detrimental effects in marine mammals, including the humpback whales mentioned above (Geraci et al. 1989, Scholin et al. 2000, Gulland et al. 2002, Doucette et al. 2006). Blooms of both genera occur at PV and offshore on the Patagonian Shelf (Carreto et al. 1986, Gayoso 2001) in a region where right whales feed after leaving the PV calving ground (Tormosov et al. 1998).

Events that kill many whales are challenging to study, and the immediate cause of death, predisposing factors and population effects have been identified in only a small fraction of cases (Dierauf \& Gulland 2001, Geraci \& Lounsbury 2005). The causes of baleen whale die-offs have mostly gone undiagnosed (Table 1). Known triggers of mortality include harmful algal blooms, human interaction (ship strikes and entanglement in fishing gear) and starvation, the lat- 
ter being suspected as a predisposing cause in deaths of eastern North Pacific gray whales (Dierauf \& Gulland 2001, NOAA 2013).

Despite analyses of hundreds of tissue samples collected from dead whales at PV, no common cause of death has been identified. Results from histopathology and biotoxin analyses will be presented in separate papers. Here, we report results of analyses to determine whether the deaths have increased beyond historical levels relative to the size of the population and whether their distribution suggests single or multiple causes. We compare the increase in number of living and dead calves counted annually over 4 decades, describe the temporal and spatial distribution of mortality events and evaluate between-year differences in the lengths of dead calves, as possible clues to the contributing factors or direct causes of death.

\section{MATERIALS AND METHODS}

\section{Effort to document right whale deaths at Península Valdés}

The effort devoted to recording living and dead whales at PV has varied over the $41 \mathrm{yr}$ of the study. Thus, it is possible that the relative number of dead calves may appear to have increased in recent years because more effort has been put into searching for them, or because living calves are increasingly underestimated, or both. These possibilities are addressed in the sections 'Declining aerial survery effort, 1971-2011' and 'Increased landbased effort to record dead whales, 1994-2002'. The number of dead whales detected in a year is derived from several sources: aerial surveys of living whales conducted throughout the calving season; reports from local residents; land-based surveys of beaches in the regions where the whales concentrate and, since 2008, varying numbers of aerial surveys of the perimeter of PV dedicated to finding dead whales.

The aerial survey protocol to photo-identify individual living whales has not changed since 1971 (Payne et al. 1983, Payne 1986). During aerial surveys, researchers fly in a small plane along the perimeter of the peninsula and photograph the individually distinctive white markings (callosities) on the heads of each whale encountered as they surface to breathe. The survey team also records the number of whales in a group, the group type (mother/calf pair, lone adult, juvenile or surface active group) and location. Locations and age-classes of dead whales that are encountered during the surveys are also recorded.

For safety reasons, the aerial survey plane must fly within gliding distance of land; thus, the surveys photograph only those whales present within $2 \mathrm{~km}$ of the tide line. Whales farther offshore but easily within view of the note-taker are counted but not

Table 1. Reports of multiple deaths of baleen whales over short periods of time

\begin{tabular}{|c|c|c|c|c|c|}
\hline Year & Deaths & Species & Location & $\begin{array}{l}\text { Cause } \\
\text { implicated }\end{array}$ & Reference \\
\hline 1987 & 14 & $\begin{array}{l}\text { Humpback whale } \\
\text { Megaptera novaeangliae }\end{array}$ & Cape Cod, MA, USA & Saxitoxin & Geraci et al. (1989) \\
\hline 1995 & $8^{\mathrm{a}}$ & $\begin{array}{l}3 \text { fin whales, Balaenoptera } \\
\text { physalus; } 1 \text { Bryde's whale, B. edeni; } \\
2 \text { minke whales, } B . \text { acutorostrata; } \\
2 \text { species unknown }\end{array}$ & $\begin{array}{l}\text { Upper Gulf of California, } \\
\text { Mexico }\end{array}$ & ? & $\begin{array}{l}\text { Vidal \& Gallo-Reynoso } \\
\text { (1996) }\end{array}$ \\
\hline 1999 & 283 & $\begin{array}{l}\text { Gray whale } \\
\text { Eschrichtius robustus }\end{array}$ & Eastern north Pacific coast & Malnutrition? & $\begin{array}{l}\text { Dierauf \& Gulland (2001) } \\
\text { Gulland et al. (2005) }\end{array}$ \\
\hline 2001 & 368 & $\begin{array}{l}\text { Gray whale } \\
\text { Eschrichtius robustus }\end{array}$ & Eastern north Pacific coast & Malnutrition? & $\begin{array}{l}\text { Dierauf \& Gulland (2001) } \\
\text { Gulland et al. (2005) }\end{array}$ \\
\hline 2009 & 10 & Species unknown & $\begin{array}{l}\text { Upper Gulf of California, } \\
\text { Mexico }\end{array}$ & $?$ & $\begin{array}{l}\text { J. Urbán-Ramírez (pers. } \\
\text { comm.) }\end{array}$ \\
\hline 2009 & 46 & $\begin{array}{l}\text { Humpback whale } \\
\text { Megaptera novaeangliae }\end{array}$ & Western Australian coast & $?$ & Coughran \& Gales (2010) \\
\hline 2010 & 96 & $\begin{array}{l}\text { Humpback whale } \\
\text { Megaptera novaeangliae }\end{array}$ & Brazil & $?$ & $\begin{array}{l}\text { M. Marcondes (pers. } \\
\text { comm.) }\end{array}$ \\
\hline $\begin{array}{l}2005- \\
2011\end{array}$ & -420 & $\begin{array}{l}\text { Southern right whale } \\
\text { Eubalaena australis }\end{array}$ & $\begin{array}{l}\text { Península Valdés, } \\
\text { Argentina }\end{array}$ & $?$ & Present study \\
\hline
\end{tabular}


photographed; thus, more whales are counted annually than photo-identified. Mother/calf pairs are the most 'catchable' individuals during surveys because they concentrate close to shore along the $5 \mathrm{~m}$ depth contour (Payne 1986) and remain at PV longer than other whales (estimated mean $=77 \mathrm{~d}$ ) (Rowntree et al. 2001). Differences between the number of whales counted in a group that was circled over and photographed and the number of whales photo-identified have not yet been resolved for years after 2000 .

Yearly estimates of the number of adult females using PV are derived from a demographically explicit population model that accounts for the observed calving sequences of all individually identified females, including a small subset of known-age females first identified as calves (Cooke et al. 2001, 2003). The model also includes parameters for the survey process. The rates and patterns of resightings allow each year's relative survey completeness to be estimated and used to infer the year's total calf output and the number of females using the PV calving ground.

Cooke's model has not been fully updated since the year 2000, so here we use raw counts of living and dead calves to ask whether the high mortality events since 2000 are truly unusual or the result of increased detection caused by increased effort to find dead calves. For this purpose, the number of living calves in a year is the count made during the single aerial photo-identification survey in that year conducted closest to the time of peak whale abundance (late September or early October) (Payne 1986). Such counts are not perfectly proportional to the actual numbers of calves produced in a year, or to the estimates made by the full demographic model. But somewhat surprisingly, these raw counts have grown at an average rate indistinguishable from the model's estimate as of 2000 (6.7 versus $6.8 \% \mathrm{yr}^{-1}$, see Fig. 3), suggesting that the gross detection efficiency of the aerial photo-ID surveys has remained approximately constant, even though the fraction of mothers photoidentified appears to have declined as the number of whales at PV has grown (Cooke et al. 2003).

Most but not all records of dead whales include date and location information to avoid duplicate counts of the same individuals. From 1971-1993, the same dead whales were often resighted on subsequent surveys within a year. Sixty-five percent of the 60 deaths recorded during this period include year and location (gulf or beach) information and 6 whales have only year information. Dead whales that were not seen during aerial surveys but were reported by local residents and researchers were added to each year's record. It is possible that some dead whales were counted more than once during this period, but probably not many because each death was a notable event and few whales died; there were 6 or fewer deaths per year from 1971-1993, with the exception of 1991 when 9 were recorded. Since 2003, the tails of dead whales have been notched and marked with an identification tag to avoid double counting. The following paragraphs describe significant changes in effort that could have influenced the number of dead whales counted each year.

Declining aerial survey effort, 1971-2011

Aerial surveys have decreased from 11 or more per year in 1971-1973 and 2 to 4 per year in 1974-1979, to 1 or 2 surveys per year in 1980-2011 (Rowntree et al. 2001).

\section{Increased land-based effort to record dead whales, 1994-2002}

In 1994, a program was established to improve the counts of dead whales sighted from land or boats. A stranding coordinator (A. Carribero) conducted bimonthly land-based surveys of the beaches where the whales concentrate, created a hotline to receive reports of strandings, established a network of local residents who gathered and forwarded reports of dead whales and involved local radio stations in asking listeners to call the hotline to report dead whales. The coordinator also measured and collected baleen, skin and blubber samples from dead whales.

Expanded effort to document every death and conduct post-mortem examinations, 2003-2011

In 2003, the Southern Right Whale Health Monitoring Program (SRWHMP) was established, and since then it has conducted post-mortem examinations of every accessible right whale that has died at PV. The stranding team is active from June through December. Members locate dead whales through land surveys of beaches, dedicated aerial surveys of the coast, reports of sightings, photo-identification surveys of living right whales and reports from members of an expanded local stranding network that includes more than 70 individuals (wildlife officers, fishermen, local inhabitants, whale-watch operators, dive-boat operators, tour-guides and other mariners, pilots, researchers and local authorities, such as the Coast 
Guard). All reports of dead whales are confirmed from land. Land and aerial survey effort by the SRWHMP has varied, but coverage has been consistently higher since 2003 than in previous years. The stranding network reports most of the dead whales found each year, but since 2008 aerial surveys dedicated to finding strandings have increased the proportion of dead whales first identified from the air.

\section{Necropsy protocol 2003-2011}

From 2003 onward, dead whales have been examined using a right whale necropsy protocol developed for the program by M. Uhart, L. La Sala and L. Pozzi, based on materials by McLellan et al. (2004), F. Gulland (pers. comm.), A. Carribero (unpubl. data) and Geraci \& Lounsbury (2005). When a stranded whale is reported, SRWHMP researchers travel as soon as possible to the stranding site. The location is recorded by GPS, the state of decay of the carcass is coded, the animal's tail is tagged and notched, photographs and body measurements are taken and an external examination is carried out in search of scars, wounds and any other evidence of the cause of death or of human interactions. Blubber thickness measurements, skin tissue and baleen plates are collected and, depending on the state of decay, an internal examination or necropsy (partial or complete) is conducted during which a full set of diagnostic samples is collected for subsequent tests.

\section{Data and analyses}

Analysis of calf mortality by years and survey effort

The counts of dead (stranded) calves as described above were used to estimate the parameters of a segmented exponential-growth model by the method of maximum likelihood estimation (MLE). The model assumes that each calf born has a probability $q_{\mathrm{s}}$ of subsequently dying and then being detected, where $\mathrm{s}$ is an index denoting the periods of differing average survey effort (1 for the period 1971-1993, 2 for the period 1994-2002, and 3 for the period 20032011). In any given year, the expected number of dead calves detected is

$$
M_{\mathrm{t}}=q_{\mathrm{s}} N_{0} \mathrm{e}^{r t}
$$

where $N_{0}$ is the number of calves born in 1971, $r$ is the annual increase in the number of mothers or calves and $t$ is years since 1971. $N_{0}$ and the 3 period- specific values of $q_{\mathrm{s}}$ cannot be estimated separately, so they reduce to 3 compound parameters $\left(n_{\mathrm{s}}=q_{\mathrm{s}} N_{0}\right)$ which are the number of dead calves expected to have been detected in 1971 under each of the 3 periods with different survey effort. The dead calves are small proportions of those born, so the numbers actually detected $\left(X_{\mathrm{t}}\right)$ are modeled as Poisson random variables with expectations $M_{\mathrm{t}}$.

Under these assumptions, a log-likelihood function for the data can be derived and partially solved. MLE point estimates of $r$ and their associated support intervals $(\Delta \ln L \leq 2)$ were found by evaluating the loglikelihood function after substitution with the closedform solutions for $n_{\mathrm{s}}$.

The null hypothesis is that $r$, the increase in number of whales using PV, has been approximately constant through all years of the study (i.e. through periods 1, 2 and 3) and that calf deaths, therefore, also have increased at that same constant rate, although they may have been detected with different efficiencies during the 3 periods. An alternative hypothesis is that calf deaths have actually increased during recent years at an average rate greater than that of the number of mothers coming to PV.

A likelihood model was not applied to the number of living calves (as estimated from counts during the annual aerial photographic surveys) because they comprise substantial proportions of the total number of living calves as estimated from the comprehensive demographic model (Cooke et al. 2003). For this reason, the number of living calves detected cannot be assumed to be Poisson distributed. Instead, standard least-squares linear regressions were set to the log-transformed counts and then the intercepts were back-transformed to obtain estimates of $n_{\mathrm{s}}$.

The counts of living calves were not adjusted upward to account for the number of calves known to have died before the aerial survey, nor downward for the number known to have died after the survey. In principle, such adjustments might improve the correlation between the number of calves observed alive in a survey and the number actually recruited from that year. However, a calf that dies and strands is more likely to be detected than a calf that does not die and strand, because stranded calves remain on the beach for days or weeks and are recorded throughout the season, while living calves are recorded only during aerial surveys which are effectively instantaneous and restricted to a narrow band of water adjacent to the shore, and thus include only a small fraction of the surface area of the 2 gulfs. To correct the counts of living calves, using information 
about dead calves, would, therefore, require fractional substitution factors, because each dead calf seen is a larger fraction of the total than is each living calf seen. There is no obvious way to estimate such factors from the available data, for the same reason that we cannot directly estimate the actual mortality rates (i.e. living and dead calves are detected with different efficiencies that can themselves be estimated only in part). Fortunately, the error introduced by failing to adjust the living-calf counts by the numbers known to have died before and after the aerial survey is expected to be small because most calves live.

The counts of living and dead calves, by year, are given in Appendix 1. The estimated exponential growth curves are also shown graphically (see Fig. 3).

\section{Low and high mortality years}

Years with fewer than 35 deaths were classified as 'low mortality' years. Any such cut-off is arbitrary; this one was chosen to distinguish those years in which experts familiar with the number of whales visiting PV did not consider the numbers of dead whales unusual, from those years in which the numbers of dead whales were, in fact, viewed as unexpectedly high. The low mortality years were combined to enable statistical comparisons with high mortality years. The low-mortality years were initially divided into 2 sets defined by survey effort as described above, to facilitate statistical analyses of the temporal patterns described in the following paragraph $7 \mathrm{yr}$ from 1994-2000 in period 2 and $3 \mathrm{yr}$ 2003, 2004 and 2006 in period 3; see Fig. 6a). Years with limited data on the days of stranding were excluded from the temporal analyses (1971-1993, 2000 and 2001).

\section{Variation in the temporal distributions of deaths}

Deaths in each year were binned into 14 halfmonth periods from early June through late December (see Fig. 5), and the yearly temporal distributions of mortality were compared by contingency-table analysis (chi-square tests) on the 6 and 8 central bins with the largest numbers of deaths in most years (from mid July through mid November). Two-bin ('early' versus 'late') distributions, lumping all deaths before October 1 versus all deaths from that date to the end of the season, were also considered. This division of the season into 2 parts (1) allocates roughly equal amounts of the overall mortality into the early and late categories, (2) divides the deaths into those consisting mainly of newborns (early) and older calves (late) (most calves are born in August and September; Whitehead \& Payne 1981, Rowntree et al. 2001) and (3) divides the adult whales into those that can be assumed to be fasting and those that might have fed on zooplankton containing biotoxins. Regardless of the number of bins considered, the same pairs of years emerged as relatively similar to each other (i.e. not significantly different from each other, or only weakly so, but highly significantly different from most other years). These pairs of similar years were combined or plotted together in subsequent analyses.

\section{Variation in the lengths of dead calves} by date of stranding

Right-whale calves grow rapidly in their first few months after birth (Best \& Rüther 1992), so calf length can be used as a crude proxy for age. All calf lengths reported here are straight-line measurements from snout-tip to fluke notch. A $10 \mathrm{~m}$ cut-off was used to distinguish calves from juveniles $(12 \mathrm{~m}$ was used to distinguish juveniles from adults) based on Best \& Rüther's (1992) photogrammetric measurements of 72 living southern right whale mother/calf pairs off South Africa, and also an analysis by Whitehead \& Payne (1981).

Among-year differences in length distributions were examined by plotting the lengths of dead calves against the day of the year on which they were found (see Fig. 6). Calves were classified as small if less than $6 \mathrm{~m}$ in length and large if $6 \mathrm{~m}$ or greater. This cut-off was chosen to distinguish stillbirths and newborns no more than a few weeks old from calves that had probably lived a month or more (Best \& Rüther 1992). October 1 was used to distinguish calves that died early or late in the calving season (as described above). Given these classifications, each dead calf fell into 1 of 4 categories (early/small, early/large, late/small, late/large). Contingency-table analyses were used to ask whether pairs of years had significantly different distributions when stranding period (early or late) was combined with calf length (large or small) $(2 \mathrm{yr}$ by 4 date/size categories, $\mathrm{df}=3$ ). Years with statistically indistinguishable patterns are plotted together (see Fig. 6). The calves from each year or set of grouped low-mortality years are indicated by different symbols. 


\section{RESULTS AND DISCUSSION}

From 1971 through 2011, 630 right whale deaths were recorded at PV. Three of the deaths were reported only as floating at sea; the remainder were found on land. Seventy-seven percent (482) of the deaths occurred from 2003-2011 (Table 2, Figs. 1 \& 2). Nine more dead whales ( 6 adults, 1 juvenile and 2 of unknown age) were found on the Argentine coast outside of PV in 2008-2010, but are not included in the analyses described here. In 2003-2011, most of the whales that died at PV were found on the coasts of Golfo San José (GSJ) and Golfo Nuevo (GN) (Fig. 1) and the largest numbers died in 2005 and 20072011 (Table 2). The sex ratio (males/total) of the 353 dead calves that could be sexed is female biased ( 0.47 males/total; for juveniles $4 / 17=0.24$ and adults $1 / 27=0.04)$.

Adults and juveniles died in unusual spatio-temporal clusters in 2005 and 2010. In 2005, 5 adults and one juvenile died in GSJ over a $17 \mathrm{~d}$ period that began with 3 females washing onto beaches separated by less than $5 \mathrm{~km}$ on the same day (Oct 19) followed by 2 more females and a juvenile in the following 16 d. In 2010, 2 adult females and 7 juveniles died in GSJ within the 2-wk period from October 27 through November 9.

\section{Calf deaths and influence of survey effort on estimated mortality}

An increase in whale numbers and an increase in survey effort would both be expected to increase the number of dead calves counted per year. Increased effort alone does not explain the pattern and scale of the recent increase in observed deaths. If actual calf deaths had been proportional to births over the duration of the study, then within each of the 3 periods with a given level of effort (indexed by 1, 2 and 3), the observed deaths would have been roughly proportional to the number of living calves

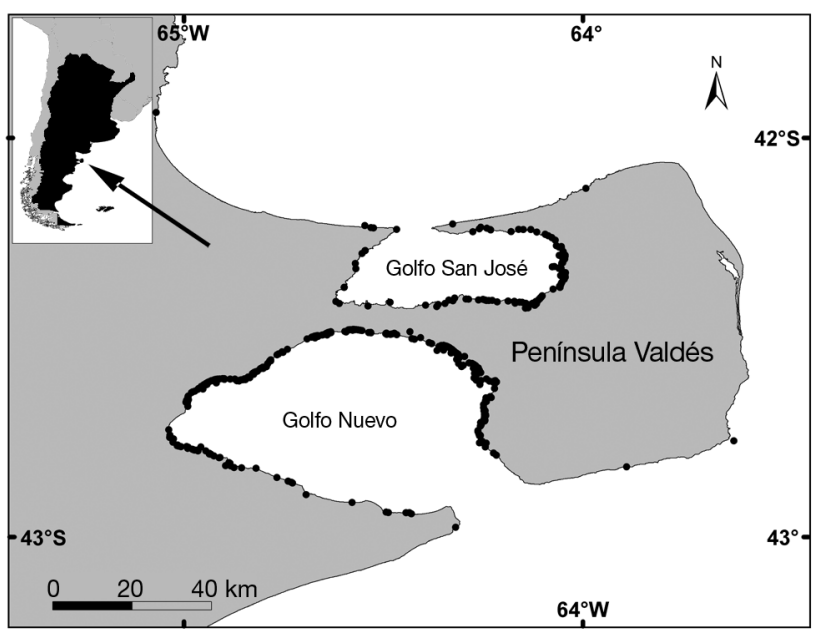

Fig. 1. Península Valdés, Argentina, with black circles indicating the locations where 482 dead right whales were found from 2003-2011

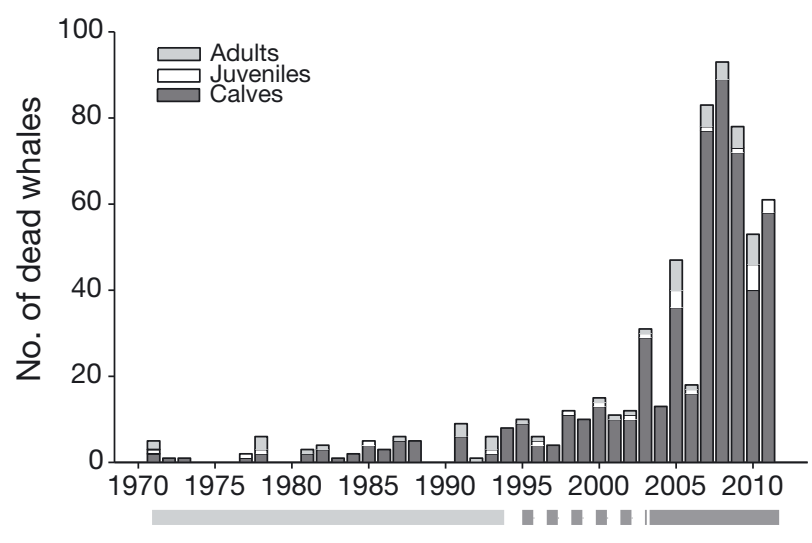

Fig. 2. Eubalaena australis. The distribution of age classes among the whales that died at Península Valdés from 1971 through 2011. Bars below the horizontal axis group years with similar effort to document dead whales (light gray = period 1, aerial surveys and reports by local residents; darker dashed bar = period 2, land-based surveys of beaches and publicly organized stranding network; dark gray = period 3, expanded stranding network and more frequent surveys of beaches from land and air)

Table 2. Eubalaena australis. The number and age categories of dead whales recorded at Península Valdés from 2003-2011; $89 \%$ of the dead whales were calves

\begin{tabular}{|lrrrrrrrrrrr|}
\hline Age & 2003 & 2004 & 2005 & 2006 & 2007 & 2008 & 2009 & 2010 & 2011 & Total & $\%$ of total \\
\hline Calves & 29 & 13 & 36 & 16 & 77 & 89 & 72 & 40 & 58 & 430 & 89 \\
Juveniles & 1 & 0 & 4 & 1 & 1 & 0 & 1 & 6 & 3 & 17 & 4 \\
Adults & 1 & 0 & 7 & 1 & 5 & 4 & 5 & 7 & 0 & 30 & 5 \\
Unknown & 0 & 0 & 0 & 0 & 0 & 3 & 2 & 0 & 0 & 5 & 1 \\
Total & 31 & 13 & 47 & 18 & 83 & 96 & 80 & 53 & 61 & 482 & 100 \\
\hline
\end{tabular}


counted each year and to the estimated number of whales using PV. During periods 1 and 2 (19712002), the number of dead calves increased at average rates $(r=0.061$ and $r=0.067$; Fig. 3a) close to the estimated growth rate of $6.8 \% \mathrm{yr}^{-1}$ (Cooke et al. 2003). However, during the years of the SRWHMP (period 3, 2003-2011), the number of dead calves appeared to increase at an average rate $(r=0.122$, 2-log support interval 0.083 to 0.161 ) (Fig. 3a), much greater than the growth rate (Fig. 3a), while the number of living calves recorded in the aerial surveys continued to rise at a modest rate $(r=0.067)$ consistent with the long-term growth rate (Fig. 3b). The living-calves growth rate estimate for period 2 $(r=0.033)$ was lower than the overall rate, but not significantly so: the standard errors on $r$ for periods 2 and 3 were approximately 0.035 because each period consists of only $9 \mathrm{yr}$ and the observed numbers of calves were highly variable; the errors were much smaller for period $1(0.013)$ and for the full sequence of $41 \mathrm{yr}(0.005)$.

Calf deaths were not unexpectedly high during every year of the SRWHMP. In 2004 and 2006, the numbers were close to those expected by extrapolation from earlier years of the study (Fig. 3a). The number of dead calves in period 3 appeared to be unusually highly variable, in addition to being high

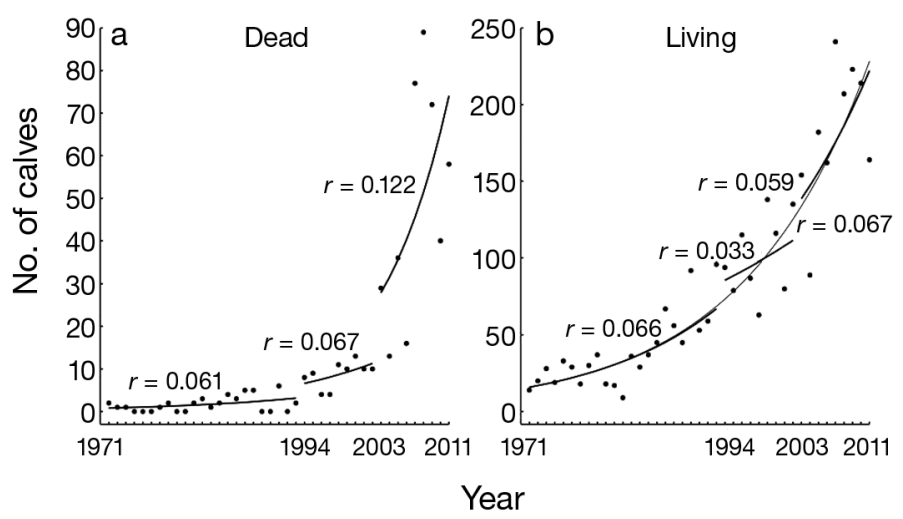

Fig. 3. Eubalaena australis. Yearly numbers of dead and living calves counted at Península Valdés, 1971-2011. The points for dead calves (a) include all individuals found within the study area through each calving season. The curves estimating growth trends are fit separately for each of the 3 periods with different levels of survey effort, as explained in 'Materials and methods'. The points for living calves (b) include only counts of individuals seen during the aerial photographic survey conducted near the time of peak abundance of mother-calf pairs. The curves estimating growth trends are fit separately for each of the 3 periods with different levels of effort directed to recording dead calves, and a curve for all years combined is also shown (thinner line) on average, relative to the numbers estimated to have been born. The variability can be characterized in several ways. For example, the coefficient of variation $\left(\mathrm{CV}=\mathrm{SD}\right.$ mean $\left.^{-1}\right)$ for the $9 \mathrm{yr}$ of period 2 was 0.35 , but for the $9 \mathrm{yr}$ of period 3 the CV was 0.57 . These ratios were expected to be approximately equal under a model of exponential growth at a constant rate but with different efficiencies of detection (caused by different levels of effort) in these 2 periods of equal length.

A contingency-table analysis showed that the variation during period 3 (but not period 2) was significantly elevated. Under the null hypothesis, the number of calves dying each year should be proportional to the number of calves actually born, regardless of any model-based assumptions about the number of adults using PV. In some ways, this is a better null hypothesis than that of exponential growth because the 3 yearly calving cohorts can vary substantially in size. The contingency $\chi^{2}$ statistic for living and dead calves over the $9 \mathrm{yr}$ of period 3 (2003-2011) was 52.0 $\left(\mathrm{df}=8, \mathrm{p}<10^{-7}\right)$ (Appendix 1). The same statistic for period 2 was $\chi^{2}=12.9(\mathrm{df}=8, \mathrm{p}<0.15, \mathrm{NS})$.

For the 23 yr of period $1, \chi^{2}=45.68(\mathrm{df}=22, \mathrm{p}<0.01)$ (Appendix 1), which suggests that the numbers of calf deaths were also highly variable during the early years of the study, but alternative explanations seem more plausible. First, the expected numbers of dead calves were very small during this period (less than 2 per year on average, and less than 1 in many years). Thus, many of the individual terms in the overall $\chi^{2}$ statistic may be artifactually inflated by small expected values in their denominators. Second, the effort devoted to finding and recording dead calves during this period was lower and probably more variable from year to year than during periods 2 and 3 . This variation in effort would be expected to add a random, non-biological component to the variation in numbers of dead calves actually found. And third, in the early years, there was also more variation in the completeness of the aerial photographic surveys that were carried out at the time of peak whale abundance, which would add non-biological variation to the numbers of live calves counted each year during period 1. For all of these reasons, we doubt that the numbers of calf deaths were really more variable in period 1 than they were in period 2 .

In summary, calves born at PV appeared to die in higher numbers that varied more strongly from year to year during the period 2003-2011 than in previous decades. Average numbers of calf deaths also appeared to be absolutely higher, but it was difficult to estimate the magnitude of this increase owing to the 
increases in effort to record dead whales that were initiated in 1994 and again in 2003.

\section{Spatial and temporal distribution of deaths and differences in dead calf lengths}

Location of dead whales 2003-2011

Most of the 430 dead calves recorded at Valdés from 2003-2011 were found in its 2 gulfs, GN and GSJ; just 3 dead calves were found along the outer coast (Fig. 1). Throughout this period, somewhat more living calves were seen in GN (58\% of the 1646 living calves counted during the annual aerial surveys at the time of peak whale abundance), but many more dead calves were found in GN (76\% of 430) than in GSJ $\left(\chi^{2}=43.7, \mathrm{df}=1, \mathrm{p}<4 \times 10^{-11}\right.$ for the classifications GN/ GSJ and living/dead). Numbers of living and dead calves seen in each gulf in each of the 9 yr 2003-2011 are shown in Fig. 4.

Golfo San José is a protected marine reserve with little boat traffic, no towns and few human inhabitants, whereas GN is home to Puerto Madryn, a small city (population about 60 000) with several industries including fish and aluminum processing. Between 1971 and 2000, human activities in GN appeared to have no effect on right-whale deaths; in these years, more dead whales were found in GSJ than in GN (55\% of 91 deaths). The higher number of calf deaths in recent years in GN could be caused by some micro-environmental difference between the 2 gulfs, but the higher proportion could also be confounded by whale movements. During years with multiple photo-identification surveys, individual whales were seen to move from GSJ into GN at the end of the calving season (V. J. Rowntree et al. 2001, unpubl. data). were almost equally divided between the early and the late periods of 2010 and 2011 (Table 3, Fig. 5d)

If the low-mortality years can be considered 'normal,' then they indicate that most calves that die on the calving ground in normal years do so shortly after birth. The deaths in 2005 and 2007 differed from this pattern because most of the deaths occurred late in the season (after October 1). In addition, as summarized in Fig. 5, there was a peak or secondary peak of calf deaths at the end of September or early in Octo-

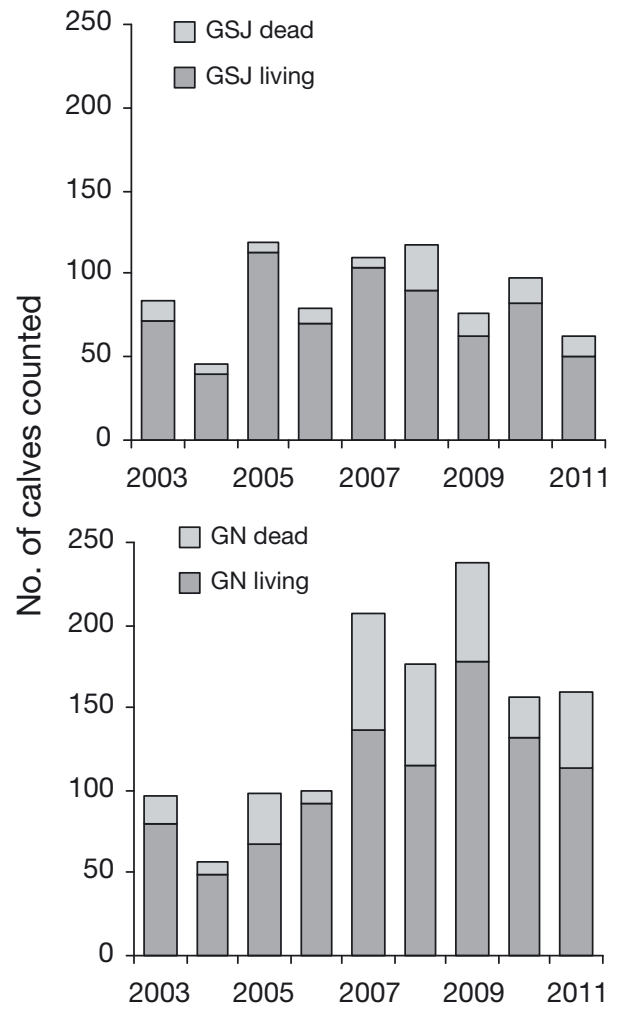

Fig. 4. Eubalaena australis. Numbers of living and dead calves recorded in Golfo San José (GSJ, upper panel) and Golfo Nuevo (GN, lower panel) in each of the years 2003-2011
Variation in the temporal distribution of deaths

Most calf deaths occurred early in the calving seasons of low-mortality years $(80 \%)$ and in 2008 and 2009 (75\%) (Table 3, Fig. 5a,c). In contrast, most calf deaths occurred late in the seasons of 2005 and $2007 \quad(75 \%)$ (Table 3, Fig. 5b). These differences were highly significant $\left(\chi^{2}\right.$ values of 13.2 or greater and $p$-values ranging from $2 \times 10^{-4}$ to $3 \times 10^{-15}$ ). Calf deaths
Table 3. Eubalaena australis. Number (n) and proportion (prop) of dead calves that were found early (pre Oct 1) or late (on or after Oct 1) in the calving season and that were greater or less than $6 \mathrm{~m}$ in length in grouped years

\begin{tabular}{|c|c|c|c|c|c|c|c|c|}
\hline & \multicolumn{2}{|c|}{ Low mortality } & \multicolumn{2}{|c|}{$2005 / 2007$} & \multicolumn{2}{|c|}{ 2008/2009 } & \multicolumn{2}{|c|}{$2010 / 2011$} \\
\hline & $\mathrm{n}$ & prop & $\mathrm{n}$ & prop & $\mathrm{n}$ & prop & $\mathrm{n}$ & prop \\
\hline \multicolumn{9}{|l|}{ Date found } \\
\hline pre Oct 1 & 79 & 0.80 & 27 & 0.25 & 105 & 0.75 & 43 & 0.47 \\
\hline post Oct 1 & 20 & 0.20 & 79 & 0.75 & 35 & 0.25 & 49 & 0.53 \\
\hline Total & 99 & 1.00 & 106 & 1.00 & 140 & 1.00 & 92 & 1.00 \\
\hline \multicolumn{9}{|l|}{ Calf size } \\
\hline$\geq 6 \mathrm{~m}$ & 19 & 0.36 & 68 & 0.64 & 60 & 0.43 & 41 & 0.45 \\
\hline$<6 \mathrm{~m}$ & 80 & 0.64 & 38 & 0.36 & 80 & 0.57 & 51 & 0.55 \\
\hline Total & 99 & 1.00 & 106 & 1.00 & 140 & 1.00 & 92 & 1.00 \\
\hline
\end{tabular}


ber in all years with the exception of 2005 and 2010, suggesting that some risk factor often comes into play at that time of year. The most obvious factor would be that the whales begin to feed on zooplankton blooms (which can be toxic) in late September and early October, before they depart for their feeding grounds later in October.

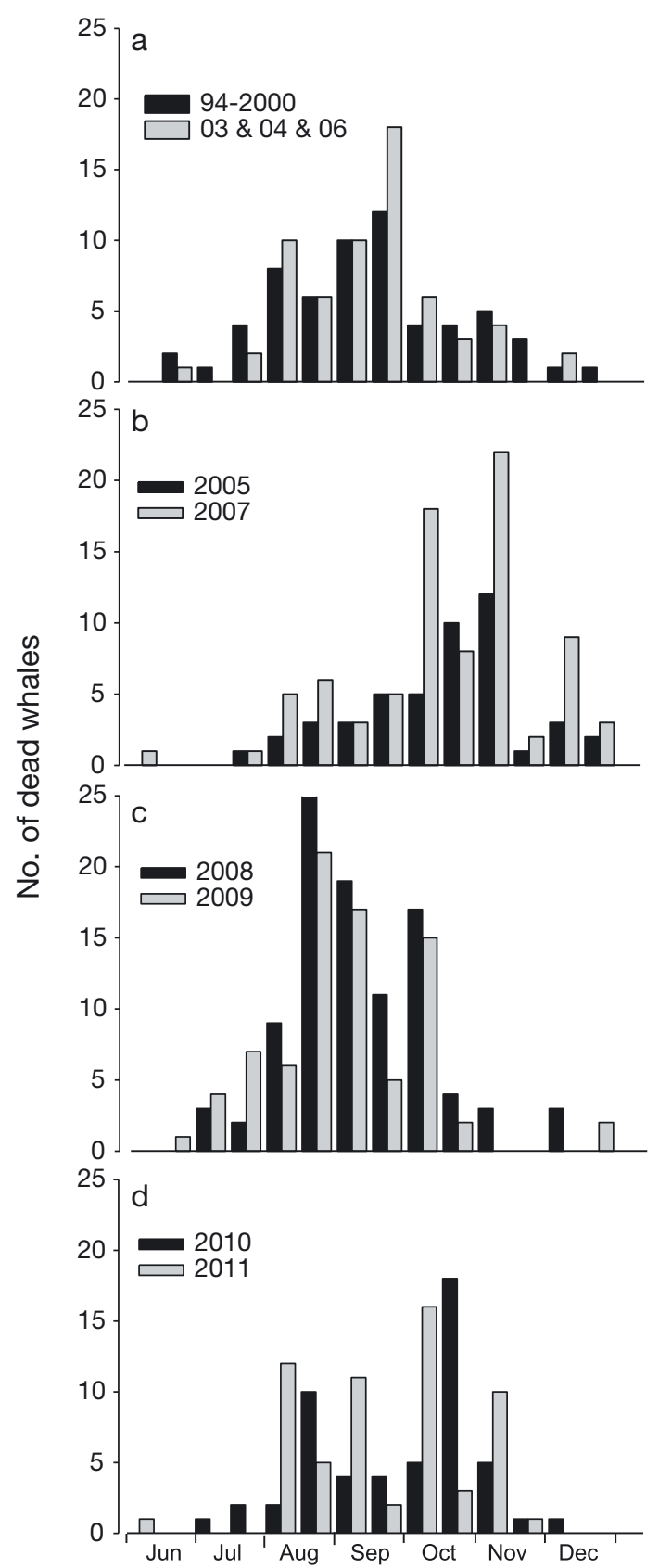

Fig. 5. Eubalaena australis. Number of whales of all ages that died in each 2 wk period from June through December in 1994-2011. (a) Low mortality years are grouped by years with similar search effort. (b-d) The remaining high mortality years are grouped by years with similar distributions of deaths before and after October 1

\section{Variation in the lengths of dead calves in relation to time of stranding}

The lengths of dead calves found between 1994 and 2011 ranged from 2.18 to $9.83 \mathrm{~m}(\mathrm{n}=437)$ and varied considerably at any given time in the season (Fig. 6), in agreement with the distribution of lengths of living right whale calves off South Africa (Best \& Rüther 1992). Small dead calves (less than $6 \mathrm{~m}$ ) were found at PV throughout the calving season, but most of them died before October 1 (74\% of 249 small calves, Table 4). However, few years appeared to be 'typical' with respect to the overall distribution of date and size at stranding. Instead, the years showed several distinct patterns, when dead calves were classified as early/ late and small/large. The sets of grouped years all differed significantly from each other when counts in the 4 panels of Fig. 6 were compared by contingency-table analyses (Table 4, Fig. 6, 4 quadrants in 2 sets of years, $\chi^{2}$ values of 15.1 or greater, df $=3, \mathrm{p}<0.002$ ).

In low-mortality years (Table 4, Fig. 6a), most of the dead calves were small (81\% of 99 dead calves), in contrast to high-mortality years when $50 \%$ of 338 dead calves were small $\left(\chi^{2}=29.7\right.$, $\mathrm{df}=1$, $\left.\mathrm{p}<0.001\right)$. Young right whale females calving for the first time off South Africa tend to give birth to smaller calves and show greater year to year variation in dates of calving than experienced mothers, while multiparous mothers tend to give birth in mid-August with little year-to-year variation in timing and their calves tend to be larger than those of smaller inexperienced mothers (Best \& Rüther 1992, Best 1994). These observations suggest that many of the small dead calves found at PV were the offspring of young females that may experience more abortions, stillbirths or neonatal deaths than older females.

In 2008 and 2009, most of the calves that died $(75 \%)$ were found before October 1 (Tables 3, Fig. 6c) and a higher proportion of these calves were large ( $\geq 6 \mathrm{~m}$ ) compared to calves that died early in all other years combined (43/105 compared to 27/149, Table 4) $\left(\chi^{2}=16.1, \mathrm{p}<0.001\right)$. Thus, in these years with apparently elevated levels of early calf mortality, an unusually large proportion of the calves were larger than expected. Given the tendency of multiparous South African right whales to give birth in mid-August and to have larger calves than primiparous females (Best \& Rüther 1992), many of the large calves that died early in 2008 and 2009 seem likely to have been the offspring of experienced mothers whose calves seldom died in other years (as implied by Fig. 6a,b). 


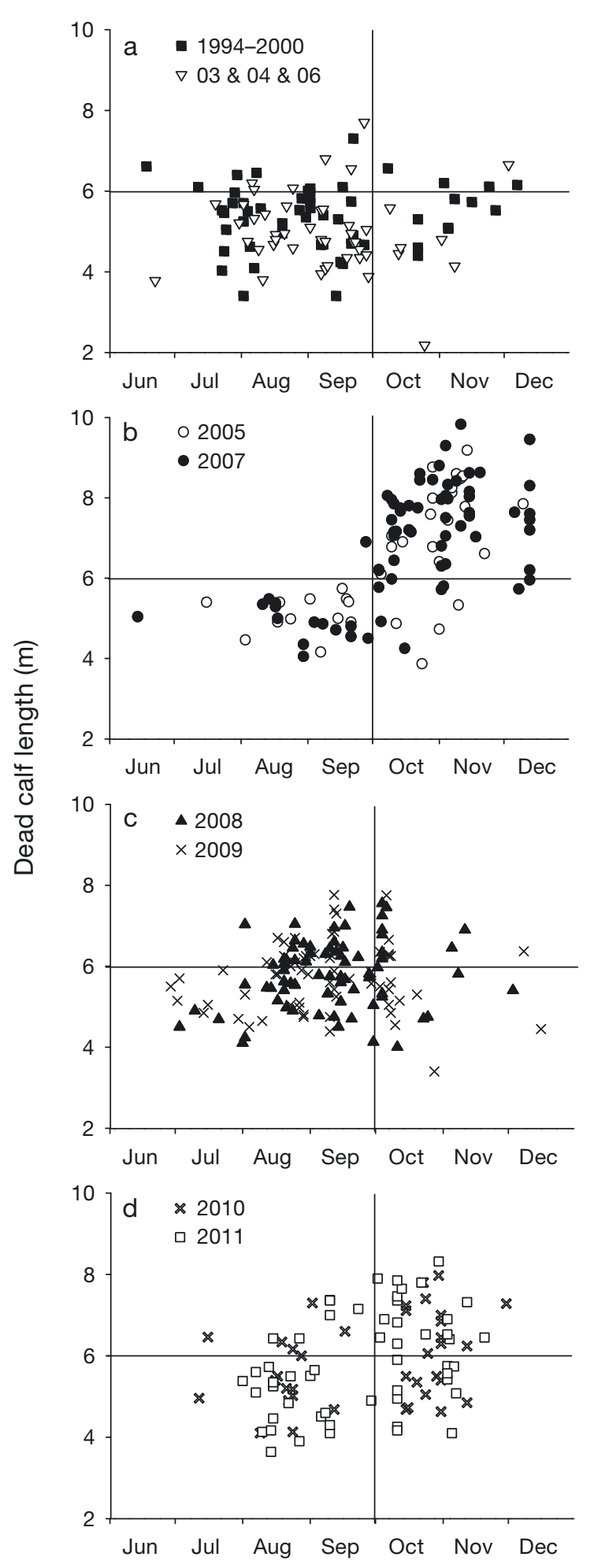

Fig. 6. Eubalaena australis. Lengths of dead calves by date of discovery for individual years and groups of years. Each symbol represents one calf. (a) Low-mortality years, (b) high latemortality years, (c) high early-mortality years, (d) mixed highmortality years. Vertical lines (Oct 1) separate 'early' from 'late' calf deaths, and horizontal lines $(6 \mathrm{~m})$ separate 'small' (typically <1 mo old) from 'large' (1 to $3 \mathrm{mo}$ ) dead calves
Table 4. Eubalaena australis. Numbers of calves in quadrants in the panels of Fig. 6. Each dead calf falls into one of the quadrants depending on its length $(<$ or $\geq 6 \mathrm{~m})$ and on the date when it was found (before or after October 1). The years defined as 'low-mortality' years are grouped, as are 3 different pairs of 'high-mortality' years, as explained in the 'Materials and methods'. All 6 of the contingency-table tests between pairs of these 4 groupings are statistically significant yielding $\chi^{2}$ values of $15.1, \mathrm{df}=3, \mathrm{p}<0.002$ or greater. For example, one of these 6 tables compares the low-mortality years (first column in the data matrix below) to 2005 and 2007 (second column). The resulting contingency table is $[(14,1),(65,26),(5,67),(15,12)]$, giving $\chi^{2}=81.6, \mathrm{p}<1 \times 10^{-6}$

\begin{tabular}{|lcrcc|}
\hline Quadrants & $\begin{array}{c}\text { Low } \\
\text { mortality }\end{array}$ & $\begin{array}{c}\text { 2005/ } \\
2007\end{array}$ & $\begin{array}{c}\text { 2008/ } \\
\text { 2009 }\end{array}$ & $\begin{array}{c}2010 / \\
2011\end{array}$ \\
\hline Early \& $\geq 6 \mathrm{~m}$ & 14 & 1 & 43 & 12 \\
Early \& <6 m & 65 & 26 & 62 & 31 \\
Late \& $\geq 6 \mathrm{~m}$ & 5 & 67 & 17 & 29 \\
Late \& $<6 \mathrm{~m}$ & 15 & 12 & 18 & 20 \\
Total & 99 & 106 & 140 & 92 \\
\hline
\end{tabular}

In 2005 and 2007, more calves died after October 1 $(75 \%)$ than in any of the other years, and most of them were large ( $85 \%$, upper right-hand quadrant of Fig. 6b, Table 3). The mean length of large calves in 2005 and 2007 was $7.8 \mathrm{~m}$, which is $1.7 \mathrm{~m}$ longer than Best's (1994) estimate of mean calf length at birth $(6.1 \mathrm{~m})$. Given a mid-August birth date and midOctober death date, the calves would have grown roughly $170 \mathrm{~cm}$ in $60 \mathrm{~d}$ or $2.8 \mathrm{~cm} \mathrm{~d}^{-1}$, which is the same as the growth rate of living calves estimated by Best \& Rüther (1992). The late-season deaths of apparently healthy calves (given their length at death), thus, seem likely to have been caused by a factor or factors that emerged shortly before the animals died. The same factor might also have caused the late season clusters of adult and juvenile deaths in 2005 and 2010.

In 2010 and 2011, 55\% of the calves that died were small (Fig. 6d), similar to what was observed in 2008 and 2009 (Table 3). However, the deaths in 2010 and 2011 were more equally distributed before and after October 1 (43:49) suggesting that more than one factor played a role in those years.

\section{CONCLUSIONS}

The varying levels and patterns of calf mortality described above strongly suggest that many of the deaths occurring at Península Valdés in recent years have an unusual cause or causes, and that the overall rate of mortality has been significantly elevated. During the 2012 calving season, as this report was being 
written, 116 whales stranded at PV. This is the largest number seen to date (previously 96, in 2008, Table 2), and all but 3 of the dead whales were calves. Accounting for recent growth of the population, around 4000 whales use PV as a calving ground (IWC 2012). Thus, the 2012 mortality amounts to nearly $3 \%$ of the western South Atlantic stock. No other known singleyear die-off of baleen whales is as large. For example, the eastern North Pacific gray whale die-off is estimated to have taken around $2 \%$ of the population in $2000(386 / 17958$, see Table 1), while the western Australian humpback die-off of 2009 (46/2775033850) and the Brazilian humpback die-off of 2012 (47/9330) each took much less than $1 \%$. Most concerning is the fact that high levels of mortality have occurred at PV in 8 of the last $10 \mathrm{yr}$.

Different environmental factors may have played leading roles in different years, as suggested by the variable temporal distributions of deaths, the variation in average sizes and presumed ages of the affected calves and the tendency for most mortality to occur in Golfo Nuevo. In the early mortality events of 2008 and 2009, a higher proportion of large $(>6 \mathrm{~m})$ calves died before October 1 than in any other year, indicating that the whales were stressed in a way that affected most females regardless of age, size and experience, suggesting something like unusually poor foraging or some other widespread environmental disturbance. In contrast, in the late mortality events of 2005 and 2007, most of the dead calves appeared to have grown more than a meter before death, suggesting that they were probably healthy prior to experiencing a sudden insult of some kind. These calves died during the time when adults begin to feed, suggesting that the deaths could be related to harmful algal blooms. Trace levels of the algal biotoxins saxitoxin (STX) and domoic acid (DA) have been found in tissues of only 4 of the 36 dead animals examined to date (G. Doucette and S. Fire pers. comm.). The levels were much below those found in the feces of foraging North Atlantic right whales (Doucette et al. 2006, 2012). The results of these and additional tissue analyses will be presented in a separate paper along with analyses of possible correlations between the temporal distribution of deaths, periods when algal blooms were known to be toxic at PV and periods when chlorophyll a levels were high in the western South Atlantic.

The International Whaling Commission convened a workshop of specialists in March 2010 to review evidence and discuss hypotheses for the recent deaths of right whales at PV (IWC 2011). Hypotheses included: changes in food availability; infectious dis- eases; local and global increases in biotoxins; exposure to environmental contaminants; gull harassment and gull peck lesions; changes in demography; predation; whale watching; fisheries interactions and vessel strikes. Participants dismissed most of these possibilities and identified 3 leading hypotheses to explain the high mortality events: (1) decreased availability of food, (2) exposure to biotoxins and (3) infectious disease. Given these recommendations and the lack of consistent findings, efforts to expand research on these main factors along with health problems associated with constant gull harassment (Rowntree et al. 1998, Thomas et al. 2013) are currently under way.

Ancillary diagnostic testing was performed on samples from a subset of the dead whales including routine histologic examination of tissues, serologic testing and PCR on select subsets of samples. To date, no consistent or significant findings, including infectious disease, have been identified within or between years to explain the ongoing, recurrent mortality events. The results of post-mortem examinations and these ancillary diagnostic tests will be described fully in a separate paper.

Analyses of essential and non-essential metals in 45 calves that died at PV in 2003-2009 found low levels of essential metals similar to ranges reported for mysticetes in other parts of the world, including bowhead whales that were killed by hunters and presumably were healthy before death. The similarity to other mysticetes suggests that toxic effects of metals are unlikely to have contributed to the deaths of these calves (Rosas et al. 2012). The levels of 25 metals in skin biopsies from 10 living adult PV females were also found to be on the low ends of the ranges of concentrations measured in other studies, suggesting no abnormal accumulation of metals in these adults (Martino et al. 2012).

Southern right whales were heavily exploited from the 17th through the 19th centuries, so there is no information about maternal reproductive rates or calf mortality rates for any right whale population near its natural carrying capacity. As the population recovers from whaling, intra- and interspecific competition for food and other ecological processes might be expected to cause negative density dependence of reproduction and survival rates. To what extent such effects may have contributed to the recent high mortality events is a difficult but potentially important question.

PV right whales appear to be sensitive to low abundances of Antarctic krill Euphausia superba. Over the first $30 \mathrm{yr}$ of the study, the PV whales had fewer 
calves than expected following years with El Niño Southern Oscillation events when sea surface temperatures (SSTs) were higher than normal off South Georgia, one of the whales' likely feeding grounds (Leaper et al. 2006). High SSTs at South Georgia are associated with declines in Antarctic krill abundance and reproductive failures of other krill predators that forage and breed at South Georgia (e.g. fur seals and Gentoo penguins) (Trathan et al. 2006). Investigations are under way to extend these analyses through 2012 and to look for correlations between some of the recent high mortality events and SST anomalies or periods with low krill abundance off South Georgia. Work is also under way to estimate female body condition from aerial survey photos and diet from baleen and blubber samples to test predictions about maternal nutritional status in years with different levels and temporal patterns of calf mortality.

Apparent declines of Antarctic krill in the western South Atlantic (Atkinson et al. 2004) are a cause for concern. Models suggest that a rate of increase of $1^{\circ} \mathrm{C}$ in mean SST in this region over the next $100 \mathrm{yr}$ could reduce Antarctic krill abundance by $95 \%$ (Murphy et al. 2007). Such a change could devastate all krill predators including the southern hemisphere baleen whales. Thus, it will be important to determine whether the elevated calf mortality events reported here could be, in part, an effect of climate change.

While many samples and data have been gathered to date, additional analyses and data from several more years will be required to identify the causes of the recurring high mortality events at PV. In particular, it will be important to monitor the population for independent or concurrent disease processes, including infectious, toxic or nutritional disease, and to gather data on the genetic and environmental factors that potentially interact with other seemingly more direct causes of the recurrent mortality now affecting young right whales at PV.

Acknowledgements. We are grateful to the Office of Protected Resources of the US National Marine Fisheries Service, National Ocean and Atmospheric Administration (Orders DG133F-02-SE-0901， DG-133F-06-SE-5823 and DG133F07SE4651), the US Marine Mammal Commission (Grants E4047315 and E4061768), the Ocean Foundation, the Island Foundation, the Pacific Life Foundation, the Lawrence Foundation, the Wildlife Conservation Society, and Ocean Alliance for funding this research. We thank those who reported and maintained the records of dead whales from 1971 through 1993, particularly G. and P. Harris, and recently more than 70 members and collaborators of the Stranding Network and volunteers and collaborators of the SRWHMP, including L.M. Pozzi, D. Taboada, R. Schtein- barg, L. Valenzuela, C. Marón, P. de Diego, and V. Rago. Invaluable support of various kinds was provided by the Instituto de Conservación de Ballenas, Fundación Patagonia Natural, and Armada Argentina. Aerial photographic surveys were pioneered by Roger Payne and conducted by him and Bernd Würsig, Chris Clark and Peter Thomas through the early decades of the study, then continued in recent decades by John Atkinson with assistance of many colleagues. Scientific guidance was kindly provided by V. Alonso Roldán, A. Friedlander, F. Gulland, J. Geraci, W. McLellan, M. Moore, S. Moore, D. Rotstein, K. Touhey, M. Hoffmeyer, V. Sastre, N. Santinelli and other colleagues to whom we are indebted. Research permits for this work were issued annually by the Dirección de Fauna y Flora Silvestre and the Subsecretaría de Turismo y Áreas Protegidas of Chubut Province, Argentina. Finally, we are extremely grateful to 4 anonymous reviewers of the manuscript who read it carefully and made many wise and penetrating suggestions that have greatly improved the result.

\section{LITERATURE CITED}

Atkinson A, Siegel V, Pakhomov E, Rothery P (2004) Longterm decline in krill stock and increase in salps within the Southern Ocean. Nature 432:100-103

Baker CS, Patenaude NJ, Bannister JL, Robins J, Kato H (1999) Distribution and diversity of mtDNA lineages among southern right whales (Eubalaena australis) from Australia and New Zealand. Mar Biol 134:1-7

Best PB (1981) The status of right whales (Eubalaena australis) off South Africa, 1969-1979. Invest Rep Sea Fish Inst S Afr 123:1-44

Best PB (1994) Seasonality of reproduction and the length of gestation in southern right whales Eubalaena australis. J Zool 232:175-189

Best PB, Rüther H (1992) Aerial photogrammetry of southern right whales, Eubalaena australis. J Zool 228:595-614

Best PB, Brandao A, Butterworth DS (2001) Demographic parameters of southern right whales off South Africa. J Cetacean Res Manag (Spec Issue) 2:161-169

Burnell S (2001) Aspects of the reproductive biology and behavioural ecology of right whales off Australia. J Cetacean Res Manag (Spec Issue) 2:89-102

Carreto JI, Benavides HR, Negri RM, Glorioso PD (1986) Toxic red-tide in the Argentine Sea. Phytoplankton distribution and survival of the toxic dinoflagellate Gonyaulax excavate in a frontal area. J Plankton Res 8:15-28

Cooke JG, Rowntree V, Payne R (2001) Estimates of demographic parameters for southern right whales (Eubalaena australis) observed off Península Valdés, Argentina. J Cetacean Res Manag (Spec Issue) 2:125-132

Cooke JG, Rowntree V, Payne R (2003) Analysis of interannual variation in reproductive success of South Atlantic right whales (Eubalaena australis) from photoidentifications of calving females observed off Península Valdés, Argentina, during 1971-2000. International Whaling Commission Scientific Committee SC/55/023, IWC, Cambridge. Available at http://iwc.int/sc-documents

Coughran D, Gales N (2010) An unusual peak in recorded mortalities of humpback whales in Western Australia: normal stochastic variability or a regional indication of carrying capacity? International Whaling Commission Scientific Committee SC/62/SH24, IWC, Cambridge

Dierauf LA, Gulland FMD (2001) Marine mammal unusual 
mortality events. In: Dierauf LA, Gulland FMD (eds) CRC Handbook of marine mammal medicine: health, disease and rehabilitation. CRC Press, Boca Raton, FL, p 69-81

- Doucette GJ, Cembella AD, Martin JL, Michaud J, Cole TVN, Rolland RM (2006) Paralytic shellfish poisoning (PSP) toxins in North Atlantic right whales Eubalaena glacialis and their zooplankton prey in the Bay of Fundy, Canada. Mar Ecol Prog Ser 306:303-313

- Doucette GJ, Mikulski CM, King KL, Roth PB and others (2012) Endangered North Atlantic right whales (Eubalaena glacialis) experience repeated, concurrent exposure to multiple environmental neurotoxins produced by marine algae. Environ Res 112:67-76

Gayoso A (2001) Observations on Alexandrium tamarense (Lebour) Balech and other dinoflagellate populations in Golfo Nuevo, Patagonia (Argentina). J Plankton Res 23: 463-468

Geraci JR, Lounsbury VJ (2005) Marine mammals ashore: a field guide for strandings, 2nd edn. National Aquarium of Baltimore, Baltimore, MD

Geraci JR, Anderson DM, Timperi RJ, St Aubin DJ, Early GA, Prescott JA, Mayo CA (1989) Humpback whales (Megaptera novaeangliae) fatally poisoned by dinoflagellate toxin. Can J Fish Aquat Sci 46:1895-1898

Gulland FMD, Hall AJ (2007) Is marine mammal health deteriorating? Trends in the global reporting of marine mammal disease. EcoHealth 4:135-150

Gulland FMD, Haulena M, Fauquier D, Lander ME, Zabka T, Duerr R, Langlois G (2002) Domoic acid toxicity in Californian sea lions (Zalophus californianus): clinical signs, treatment and survival. Vet Rec 150:475-480

Gulland FMD, Perez-Cortes H, Urban J, Rojas-Bracho L and others (2005) Eastern North Pacific gray whale (Eschrichtius robustus) unusual mortality event, 1999-2000. U.S. Dept Commerce, NOAA Tech Memo. NMFS-AFSC150, NOAA, Seattle, WA

Hoffmeyer MS, Lindner MS, Carribero A, Fulco K and others (2010) Planktonic food and foraging of Eubalaena australis, on Península Valdés (Argentina) calving ground. Rev Biol Mar Oceanogr 45:131-139

IWC (International Whaling Commission) (2001) Report of the workshop on the comprehensive assessment of right whales: a worldwide comparison. J Cetacean Res Manag (Spec Issue) 2:1-60

IWC (International Whaling Commission) (2011) Report of the Southern right whale die-off workshop. 15-18 March 2010, Centro Nacional Patagónico, Puerto Madryn, Argentina. J Cetacean Res Manag 12 (Suppl):367-398

IWC (International Whaling Commission) (2012) Report of the IWC workshop on the assessment of southern right whales 13-16 September 2011, Palacio San Martin, Buenos Aires, Argentina IWC Scientific Committee SC/ 64/Rep5, IWC, Cambridge, p 1-39 (IWC.int/sc64docs, REPS, SC-64-Rep5.pdf)

IUCN (International Union for Conservation of Nature) (2013) The IUCN Red List of threatened species version 2013.1. IUCN, Cambridge. Available at www.iucnredlist.org

Knowlton AR, Kraus SD, Kenney RD (1994) Reproduction in North Atlantic right whales (Eubalaena glacialis). Can J Zool 72:1297-1305

> Leaper R, Cooke J, Trathan P, Reid K, Rowntree VJ, Payne $\mathrm{R}$ (2006) Global climate drives southern right whale (Eubalaena australis) population dynamics. Biol Lett 2: 289-292

Martino J, Wise SS, Perkins C, Kerr I, Rowntree VJ, Sironi
M, Wise JP Sr (2012) Metal levels in southern right whales (Eubalaena australis) skin biopsies from Península Valdés, Argentina. SC/64/BRG7 presented to the International Whaling Commission Scientific Committee, Panama (unpubl.), IWC, Cambridge (Available from the IWC Office)

McLellan W, Rommel S, Moore M, Pabst D (2004) Right whale necropsy protocol. Final Report to NOAA Fisheries for contract \# 40AANF112525. U.S. Department of Commerce, National Oceanic and Atmospheric Administration, National Marine Fisheries Service, Office of Protected Resources, Silver Spring, MD

> Murphy EJ, Trathan PN, Watkins JL, Reid K and others (2007) Climatically driven fluctuations in Southern Ocean ecosystems. Proc R Soc B 274:3057-3067

NOAA (National Oceanic and Atmospheric Administration) (2013) Marine mammal unusual mortality events. Fisheries Office of Protected Resources, www.nmfs.noaa. gov/pr/health/mmume/

> Patenaude NJ, Portway VA, Schaeff CM, Bannister JL and others (2007) Mitochondrial DNA diversity and population structure among southern right whales (Eubalaena australis). J Hered 98:147-157

Payne R (1986) Long term behavioral studies of the southern right whale (Eubalaena australis). Rep Int Whal Comm (Spec Issue) 10:161-167

Payne R (1995) Among whales. Scribner, New York, NY, p 93-141

Payne R, Brazier O, Dorsey EM, Perkins JS, Rowntree VJ, Titus A (1983) External features in southern right whales (Eubalaena australis) and their use in identifying individuals. In: Payne R (ed) Communication and behavior of whales, AAAS Selected Symposia Series 76, Westview Press, Boulder, CO, p 371-445

Pettis H (2009) North Atlantic right whale consortium annual report card (01 November 2007-30 April 2009. International Whaling Commission's Document SC/61/ BRG11, IWC, Cambridge

Portway V (1998) Genetic population structure of South Atlantic right whales (Eubalaena australis). Masters thesis, American University, Washington, DC

Rosas CL, Gil MN, Uhart MM (2012) Trace metal concentrations in southern right whale (Eubalaena australis) at Penísula Valdés, Argentina. Mar Pollut Bull 64: 1255-1260

Rowntree VJ, MacGuiness P, Marshall K, Payne R, Seger J, Sironi M (1998) Increased harassment of right whales (Eubalaena australis) by kelp gulls (Larus dominicanus) at Península Valdés, Argentina. Mar Mamm Sci 14: 99-115

Rowntree VJ, Payne RS, Schell DS (2001) Changing patterns of habitat use by southern right whales (Eubalaena australis) on their calving ground at Península Valdés, Argentina and their long-range movements. J Cetacean Res Manag (Spec Issue) 2:133-143

Scholin CA, Gulland F, Doucette DJ, Benson S and others (2000) Mortality of sea lions along the central California coast linked to a toxic diatom bloom. Nature 403:80-84

Sironi M (2004) Behavior and social development of juvenile southern right whales (Eubalaena australis) and interspecific interactions at Península Valdés, Argentina. PhD dissertation, University of Wisconsin, Madison, WI

Thomas PO, Taber SM (1984) Mother-infant interaction and behavioral development in southern right whales, Eubalaena australis. Behaviour 88:42-60 
Thomas PO, Uhart M, McAloose D, Sironi M and others (2013) Workshop on the Southern right whale die-off at Peninsula Valdes, Argentina. Scientific Committee of the International Whaling Commission's Document SC/65a/ BRG15, IWC, Cambridge

Tormosov DD, Mikhaliev YA, Best PB, Zemsky VA, Sekiguchi K, Brownell RL (1998) Soviet catches of southern right whales Eubalaena australis 1951-1971. Biological data and conservation implications. Biol Conserv 86: 185-197

Trathan PN, Murphy EJ, Forcada J, Croxall JP, Reid K, Thorpe S (2006) In: Boyd IL, Wanless S, Camphuysen CJ (eds) Top predators in marine ecosystems. Cambridge University Press, Cambridge, p 28-45

Uhart M, Rowntree VJ, Mohamed N, Pozzi L and others (2008) Strandings of southern right whales (Eubalaena australis) at Península Valdés, Argentina from 20032007. Scientific Committee of the International Whaling Commission's Document SC/60/BRG15, IWC, Cambridge

Valenzuela LO, Sironi M, Rowntree VJ, LaSala L and others (2010) Population genetic structure of living and dead southern right whales (Eubalaena australis) off Península Valdés, Argentina. Scientific Committee of the International Whaling Commission's Document SC/62/BRG15, IWC, Cambridge

Vidal O, Gallo-Reynoso JP (1996) Die-offs of marine mammals and sea birds in the Gulf of California, Mexico. Mar Mamm Sci 12:627-635

Whitehead HP, Payne R (1981) New techniques for assessing populations of right whales without killing them. FAO Fish Ser 5, Vol III, Mammals in the seas:189-209

Appendix 1. Number of dead and live calves and dead older whales recorded at Península Valdés, by year, during 3 periods with increasing effort to record dead whales. Living calves were estimated as counts during the aerial survey nearest in time to peak abundance. $\mathrm{d} / \mathrm{l}$ : ratio of dead to living calves; $\chi^{2}$ : contribution of each year to the contingency chi-square statistic for a given period; for each period's total $\chi^{2}$, the df and $\mathrm{p}$-value are provided. NS: non-significant

\begin{tabular}{|c|c|c|c|c|c|c|c|c|c|c|c|c|c|}
\hline \multirow{2}{*}{ Year } & \multicolumn{4}{|c|}{ Calves } & \multirow{2}{*}{$\begin{array}{c}\text { Dead } \\
\text { juveniles }\end{array}$} & \multirow{2}{*}{$\begin{array}{l}\text { Dead } \\
\text { adults }\end{array}$} & \multirow{2}{*}{ Year } & \multicolumn{4}{|c|}{ Calves } & \multirow{2}{*}{$\begin{array}{c}\text { Dead } \\
\text { juveniles }\end{array}$} & \multirow{2}{*}{$\begin{array}{l}\text { Dead } \\
\text { adults }\end{array}$} \\
\hline & Dead & Live & $\mathrm{d} / \mathrm{l}$ & $\chi^{2}$ & & & & Dead & Live & $\mathrm{d} / \mathrm{l}$ & $\chi^{2}$ & & \\
\hline \multicolumn{7}{|c|}{ Period 1} & \multicolumn{7}{|c|}{ Period 2} \\
\hline 1971 & 2 & 14 & 0.143 & 2.60 & 1 & 2 & 1994 & 8 & 94 & 0.085 & 0.00 & & \\
\hline 1972 & 1 & 20 & 0.050 & 0.01 & 0 & 0 & 1995 & 9 & 79 & 0.114 & 0.59 & 0 & 1 \\
\hline 1973 & 1 & 28 & 0.036 & 0.05 & 0 & 0 & 1996 & 4 & 115 & 0.035 & 3.49 & 1 & 1 \\
\hline 1974 & 0 & 19 & 0.000 & 0.86 & 0 & 0 & 1997 & 4 & 87 & 0.046 & 1.61 & 0 & 0 \\
\hline 1975 & 0 & 33 & 0.000 & 1.49 & 0 & 0 & 1998 & 11 & 63 & 0.175 & 4.71 & 1 & 0 \\
\hline 1976 & 0 & 29 & 0.000 & 1.31 & 0 & 0 & 1999 & 10 & 138 & 0.072 & 0.32 & 0 & 0 \\
\hline 1977 & 1 & 18 & 0.056 & 0.04 & 1 & 0 & 2000 & 13 & 116 & 0.112 & 0.75 & 1 & 1 \\
\hline 1978 & 2 & 30 & 0.067 & 0.29 & 1 & 3 & 2001 & 10 & 80 & 0.125 & 1.17 & 0 & 1 \\
\hline 1979 & 0 & 37 & 0.000 & 1.67 & 0 & 0 & 2002 & 10 & 135 & 0.074 & 0.24 & 1 & 1 \\
\hline 1980 & 0 & 18 & 0.000 & 0.81 & 0 & 0 & Total & 79 & 907 & 0.087 & 12.89 & {$[\mathrm{df}=8, \mathrm{p}=0.12$} & NS] \\
\hline 1981 & 2 & 17 & 0.118 & 1.78 & 0 & 1 & $10 \mathrm{ldl}$ & 79 & 907 & $0.00 t$ & 12.09 & {$[\mathrm{ul}=0, \mathrm{p}=0.12$} & IVS] \\
\hline 1982 & 3 & 9 & 0.333 & 12.44 & 0 & 1 & \multicolumn{7}{|c|}{ Period 3} \\
\hline 1983 & 1 & 36 & 0.028 & 0.23 & 0 & 0 & 2003 & 29 & 154 & 0.188 & 2.55 & 1 & 1 \\
\hline 1984 & 2 & 29 & 0.069 & 0.34 & 0 & 0 & 2004 & 13 & 89 & 0.146 & 3.87 & 0 & 0 \\
\hline 1985 & 4 & 37 & 0.108 & 2.94 & 1 & 0 & 2005 & 36 & 182 & 0.198 & 2.25 & 4 & 7 \\
\hline 1986 & 3 & 45 & 0.067 & 0.44 & 0 & 0 & 2006 & 16 & 162 & 0.099 & 14.72 & 1 & 1 \\
\hline 1987 & 5 & 67 & 0.075 & 1.21 & 0 & 1 & 2007 & 77 & 241 & 0.320 & 2.50 & 1 & 5 \\
\hline 1988 & 5 & 56 & 0.089 & 2.23 & 0 & 0 & 2008 & 89 & 207 & 0.430 & 16.13 & 0 & 4 \\
\hline 1989 & 0 & 45 & 0.000 & 2.03 & 0 & 0 & 2009 & 72 & 241 & 0.299 & 1.08 & 1 & 5 \\
\hline 1990 & 0 & 92 & 0.000 & 4.15 & 0 & 0 & 2010 & 40 & 214 & 0.187 & 3.69 & 6 & 7 \\
\hline 1991 & 6 & 53 & 0.113 & 4.90 & 0 & 3 & 2011 & 58 & 165 & 0.352 & 3.95 & 3 & 0 \\
\hline 1992 & 0 & 59 & 0.000 & 2.66 & 0 & 1 & Total & 430 & 1655 & 0.260 & 50.74 & {$[\mathrm{df}=8, \mathrm{p}<0.0$} & \\
\hline 1993 & 2 & 96 & 0.021 & 1.23 & 1 & 3 & & & & & & & \\
\hline Total & 40 & 887 & 0.045 & 45.68 & \multicolumn{2}{|c|}{$[\mathrm{df}=22, \mathrm{p}=0.002]$} & & & & & & & \\
\hline
\end{tabular}

Editorial responsibility: Christine Paetzold, Oldendorf/Luhe, Germany
Submitted: December 20, 2012; Accepted: August 7, 2013 Proofs received from author(s): November 13, 2013 